\title{
テント上無症候性未破裂脳動脈瘤の治療方針
}

貫井英明堀越徹 八木下 勉 杉田 正夫

\section{Strategy of Treatment in Cases with Supratentorial Asymptomatic Unruptured Cerebral Aneurysm \\ by}

Hideaki Nukui, M.D., Tohru Horikoshi, M.D., Tsutomu Yagishita, M.D., and Masao Sugita, M.D.

from

Department of Neurosurgery, Yamanashi Medical University

To determine the surgical indication of supratentorial asymptomatic unruptured cerebral aneurysms (SAUCAs), we investigated the literature regarding the natural history of and surgical result for SAUCAs. We obtained the following results: 1) The annual rupture rate of SAUCAs is estimated at approximately 1 to $2 \%$, except for a very low rupture rate suggested by International Cooperative Study because it seemed to be highly biased regarding patient selection ; 2) Small aneurysms $(<5 \mathrm{~mm})$ and aneurysms harbored in elderly patients over 70 years of age have a chance of rupture ; 3 ) Surgical mortality and morbidity is $1 \%$ and $4 \%$, respectively, and ; 4) In the present situation, direct surgery should be considered as the primary option of treatment.

Based on the above mentioned reasons, surgical indication of SAUCAs is valid on persons who can manage ordinary daily life without severe systemic disease even if they are over 70 years of age, and who present with nongiant aneurysm including small aneurysms $(<5 \mathrm{~mm})$. On the other hand, in cases of giant aneurysm, the age of the patient should be less than 70 .

(Received September 4, 2001; accepted November 13, 2001)

Key words : strategy of treatment, supratentorial portion, asymptomatic aneurysm, unruptured aneurysm, cerebral aneurysm

Jpn J Neurosurg (Tokyo) $11: 339-346,2002$

\section{はじめに}

無症候性未破裂脳動脈瘤は破裂脳動脈瘤に合併した $\eta ，$ 他の頭蓋内疾患の精查中に発見されるのが普通で あった。近年はいわゆる脳ドックが普及したため偶然発 見される例が增加し, 出血予防を目的として直達手術が さかんに行われている。しかし，最近発表された国際共 同研究 ${ }^{30)}$ により, 偶然発見された最大径 $10 \mathrm{~mm}$ 末満の 未破裂脳動脈瘤での出血率が非常に低いことが示され， その手術適応に関し議論が起きている。 そこでテント上 無症候性未破裂脳動脈瘤の自然歷，手術成績等をこれま
で発表された文献および自験例で分析し, 現在妥当と思 われる治療方針は何かを検討した。

\section{頻 度}

破裂脳動脈瘤に合併して未破裂脳動脈瘤が発見される 頻度は大体 $20 \%$ といわれてきたが, 最近は診断機器の 技術の改良・進歩により, 上り高率に発見されるとの報 告が多い21).

破裂脳動脈溜合併例を除く未破裂脳動脈瘤の発生頻度 に関しては詳しい報告はないが, 厚生省研究班の脳神経

山梨医科大学脳神経外科 / $\overline{7}$ 409-3898 山梨県中巨摩郡玉穂町下河東 1110 [連絡先：貫井英明〕

Address reprint requests to: Hideaki Nukui, M.D., Department of Neurosurgery, Yamanashi Medical University, 1110 Shimokato,

Tamaho-cho, Nakakoma-gun, Yamanashi 409-3898, Japan 
外科学会専門医訓練施設を対象とした全国調査 ${ }^{6)}$ によれ ば，正確な症例数を回答した 271 施設では 1998 年の 1 年 間に5,707例の未破裂脳動脈瘤例が登録されている。こ れらの症例に含まれている症候性例の例数は少ないと推 定され，また同時に $37 \%$ の施設より登録された 12,000 例以上の破裂脳動脈瘤例の $20 \%$ 以上に伴う未破裂脳動 脈瘤は調查対象に入っていないこと，および回答したの は $24 \%$ の施設のみであったことを考えると，無症候性 未破裂脳動脈瘤は毎年少なくとも 8,000 例以上が発見さ れていると推定される。

一方, 現在最も問題となっている脳ドック受診者での 無症候性未破裂脳動脈瘤の発見率は, MRAの撮像と読 影の工夫が十分行われた場合は中高年者で $5 \%$ 以上であ り, 加路とともに発見率は上昇し 40 歳代 $3.6 \%, 50$ 歳代 $5.5 \% ， 60$ 歳代 $9.2 \% ， 70$ 歳代 $9.4 \%$ であると報告されて いる

\section{出血率}

無症候性未破裂脳動脈瘤の出血率に関しては以前より 報告があるが, 対象症例数が少ない報告や分析法に問題 がある報告が多い.

そこで本項では, 比較的症例数が多く, 分析法も問題 がないと思われる 1990 年以後の報告において, 特にテ ント上無症候性未破裂脳動脈溜の出血率に関し検討し た。ただし国際共同研究に関しては, 問題点が多いため 別に記載した。

\section{1 破裂脳動脈瘤に合併した例}

破裂脳動脈溜のみを手術し, 合併した未破裂脳動脈溜 は観察する方針をとりその経過を追跡したJuvela ら ${ }^{8)}$ は 平均年龄 41.7 歳の 131 例で年間出血率を $1.3 \%$ と報告し ている。この報告には脳底動脈瘤例 5 例が含まれている が, 追跡期間中は出血を生じていないため, テント上未 破裂脳動脈瘤の出血率は $1.3 \%$ より多少高い可能性があ る.また, 内頸動脈瘤および中大脳動脈瘤に比べ前交通 動脈瘤で出血率が高いとしているが, 前交通動脈瘤の数 （8個）が著しく少ない，さらに，脳動脈瘤が大きいほ ど出血率が高く, 男性例に比べ女性例で出血率が高いこ と,および出血例は非出血例に比へ脳動脈瘤発見時の年 秢が若いことが示されている.

Yasui ${ }^{34)}$ は他の理由で発見された例を含む平均年歯 59.6 歳の 234 例のうち, 破裂脳動脈瘤に伴う未破裂脳動 脈瘤例 60 例の検討で年間出血率を $3.2 \%$ とし, 累積出血 率を 10 年で $9 \%, 15$ 年で $32.5 \%$ としている. しかし対象
例の $21 \%$ 追跡できていないため, それら症例の追跡 結果によっては出血率が変化してしまう可能性がある. また, 脳動脈瘤存在部位に関する記述がないため, テン 卜上未破裂脳動脈瘤の出血率は不明である。しかし， 234 例全体での出血率はテント下脳動脈溜が $2.0 \%$ でテ ント上脳動脈瘤が $2.7 〜 3.7 \%$ あること, および他疾患 で発見された未破裂脳動脈瘤例の年間出血率が $2.2 \sim$ $3.6 \%$ と破裂脳動脈瘤に伴う未破裂脳動脈瘤の出血率と 大差がないことから，テント上未破裂脳動脈溜の年間出 血率は $3.2 \%$ よりや高い程度と推定される.さらに本 報告では, 性別, 年路および単発例か多発例かによって 年間出血率に差がないことが示されているが, 動脈溜の 大きさとの関係には触れられていない.

\section{2 頭蓋内疾患を伴って発見された例}

前述した Yasui らの報告 ${ }^{34)}$ では, 年間出血率および累 積出血率は, 脳梗塞例で $2.2 \%, 10$ 年で $20 \%$, 脳内血腫 例で $3.2 \%, 5$ 年で $9.6 \%$, その他の例で $3.6 \%, 10$ 年で $34 \%$ としてる。ここでも脳動脈溜存在部位別の值は 示されていないが, 前出の理由でテント上未破裂脳動脈 瘤の年間出血率は示された值とほぼ同じと推定される。

\section{3 脳動眽瘤の発見率とクモ膜下出血の頻度から の推定值}

Rosen $\varnothing \mathrm{rn} ら^{22)}$ は未破裂脳動脈熘の発見率を $0.5 \%$ ，ク モ膜下出血の頻度を人口 10 万人当たり 10 人として計算 し，年間出血率を $2.0 \%$ とした。

㖘藤 ${ }^{23)}$ は 40 歳以上の例で, クモ膜下出血の頻度を 5 万人当たり 20 人とし, 未破裂脳動脈瘤の頻度を $3 \%$ とす ると年間破裂率は $1.3 \%$, 頻度を $4 \%$ とすると $1.0 \%$ であ ると報告している。

また, 端ら ${ }^{5)}$ は脳ドックにおける未破裂脳動脈瘤の発 見率と久山町でのクモ膜下出血発症頻度 ${ }^{13)}$ をとに年 代別に年間出血率を計算し，40～59歳 $0.77 \% ， 60$ 歳代 $1.06 \%, 70$ 歳代 $1.94 \%$ と報告している.

さらにIwamoto $~^{7)}$ は， 30 年間で行った 1,230 例の剖 検例で脳動脈瘤が 57 例 $(4.6 \%)$ 発見され, うち 29 例で破 裂脳動脈藘が認められたため, 年間出血率は $1.7 \%$ 以上 であるとしているが，6例の椎骨脳底動脈瘤が含まれて いるためテント上例の年間出血率はより低いと思われる.

\section{(4) その他}

Rinkel ${ }^{20)}$ はそれまでの文献をレビューして，9編の 報告から 3,907 例を集め, 破裂脳動脈溜に伴う未破裂脳 動脈瘤で $1.4 \%, そ の$ 他の無症候性未破裂脳動脈瘤で 
$0.8 \%$ という年間出血率を示しているが，その他の因子 に関する詳しい分析はされていない.

菅ら ${ }^{27)}$ は 14 施設の症例 590 例の観察中 45 例 $(7.6 \%)$ が 出血を生じたとし, 年間出血率は $2.8 \%$ と報告しているが, 大きさ, 性別等の因子に関する分析は示されていない.

\section{5 国際共同研究の結果}

1998年に New Engl J Medに発表された国際共同研究 では ${ }^{30)} ， 53$ 施設で 21 年間に経験した 1,449 例を平均 8.3 年追跡している，その結果，破裂脳動脈瘤に伴う未破裂 脳動脈瘤 722 例での年間出血率は最大径 $10 \mathrm{~mm}$ 未満の例 で $0.56 \% ， 10 \mathrm{~mm}$ 以上の例で $0.64 \%$ ，さらに偶然発見し た 727 例での年間出血率は, 最大径 $10 \mathrm{~mm}$ 末満の例で $0.05 \%, 10 \mathrm{~mm}$ 以上では $0.95 \%$ と報告した。

本報告で年間出血率が他論文より低い原因は，通常ク モ膜下出血を生じない海綿静脈洞部動脈瘤がそれぞれ $9.5 \%$ と $16.9 \%$ 含まれているためではないかとの指摘に 対し, 著者らは海綿静脈洞部動脈瘤を除外しても各群に おける年間出血率は最大径 $10 \mathrm{~mm}$ 末満の例で $0.60 \%$ と $0.07 \%, 10 \mathrm{~mm}$ 以上の例で $0.72 \%$ と $1.38 \%$ であると反論 している31).

しかし本研究は後向き調查であり, 長期間の登録にも かかわらず参加した一施設当たりの登録症例数が 2 例に 満たず非常に少ないことに加え ${ }^{1)}$ ，同時に発表された前 向き調查と比べても海綿静脈洞部動脈瘤が極端に多く, 前交通動脈瘤が少ないことや $5 \mathrm{~mm}$ 未満の動脈溜が多い ことなどから，出血の危険性の低い例が登録された可能 性が高いと推定される。

実際にクモ膜下出血の年間発生頻度を人口 10 万人当 たり 10 人とすると，年間出血率が $0.05 \%$ であば，人 口 10 万人当たり 2 万人が大きさ $10 \mathrm{~mm}$ 未満の未破裂脳 動脈瘤を有する計算になり ${ }^{24)}$ ，これまで報告されている 未破裂脳動脈瘤の頻度とあまりにもかけ離れた值とな る.さらに大きさ $5 \mathrm{~mm}$ 以下の脳動脈瘤の比率を変える ことにより，出血の危険に関する大きさの閾値を何 $\mathrm{mm}$ にでも設定できるとの指摘もある4).

以上のように国際共同研究に関してはさまざまな問題 点が指摘されており，未破裂脳動脈瘤の年間出血率を推 定する基準として採用することはできないと考えられる.

\section{6 出血率のまとめ}

以上述べてきたように，テント上の無症候性未破裂脳 動脈瘤の出血率は分析の対象とした症例によって異な り，正確な出血率は無作為抽出法による多数例での長期 間の検討が必要と思われるが,これまでの報告結果を総
合すると，発見された年歯，きっかけにかかわらず，年 間1〜2\%の出血率であると考えてよい（Table 1).

\section{脳動眽瘤の大きさと出血率}

小さい脳動脈瘤ほど出血率は低いとする報告が多い が, Juvela $ら^{8)}$ は出血率は低いが，出血を生じた 24 個の うち $6 \mathrm{~mm}$ 以下の動脈瘤が 17 個（70\%）を占めたとし， Yasui $5^{33)}$ も出血例 25 例中 16 例 $(64 \%)$ が初診時 $5 \mathrm{~mm}$ 以下の動脈瘤であったとしている．また，菅ら ${ }^{27)}$ は出 血例 45 例中 7 例（15\%）が5 $\mathrm{mm}$ 以下であったと報告し ている.

一方，破裂脳動脈瘤の大きさに関し Kassell ら ${ }^{9)}$ は $15 \%$ が $5 \mathrm{~mm}$ 末満, Rosemørn ら ${ }^{22)}$ は $18 \% か ゙ ~ 5 \mathrm{~mm}$ 未満, Orz ${ }^{17)}$ は $5 \mathrm{~mm}$ 以下が $38 \%$ と報告しており，最近のわ

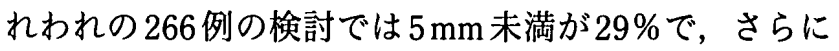
$3 \mathrm{~mm}$ 以下が $16 \%$ を占めていた。

\section{年齢と出血率}

Juvela $ら^{8)}$ は出血例で非出血例に比べ動脈溜発見時の 年齢が若いと述べている。しかし, Rinkel ら ${ }^{20)}$ は高齢 者ほど出血率が高くなるとしており, 端らちも，脳ドッ クでの未破裂脳動脈瘤の発見率は年齢とともに上昇し, クモ膜下出血の発症率も上昇するため, 年間出血率も年 齢とともに高くなるとしている.

さらに破裂脳動脈瘤に関しては 70 歳以上の高踰者の 占める割合が年々増加し, 現在は破裂脳動脈溜例の約 $1 / 3$ を占め, しかも若年者に比べ来院時重症例の頻度が 高いこと，および手術成繢は重症例では著しく不良であ るが，軽症例ではあまり変わらないことも報告されてい $ろ^{15) 32)}$.

\section{出血後の転機}

未破裂脳動脈瘤が出血を生じた場合の死亡率に関して は, Yasui ${ }^{34)}$ は $44 \%$, 菅ら ${ }^{27)}$ は $71 \%$, 国際共同研

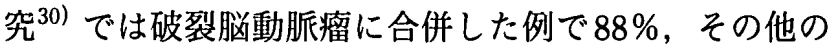
例で55\%と報告している。

\section{手術成績}

テント上無症候性未破裂脳動脈瘤の手術成績に限定し て検討した報告はないため, 近年発表され比較的多数例 の結果を報告している文献の結果を分析し，テント上無 
Table 1 Annual bleeding rate in cases of supratentorial asymptomatic unruptured aneurysms

\begin{tabular}{|c|c|c|c|c|c|c|}
\hline Authors & Year & $\begin{array}{c}\text { Annual } \\
\text { bleeding } \\
\text { rate }(\%)\end{array}$ & $\begin{array}{l}\text { No. of } \\
\text { cases }\end{array}$ & $\begin{array}{l}\text { Mean age } \\
\text { (years old) }\end{array}$ & $\begin{array}{c}\text { Mean } \\
\text { follow-up } \\
\text { period }\end{array}$ & Others \\
\hline Juvela, et al ${ }^{8)}$ & 1993 & 1.3 & 131 & 41.7 & 13.9 Yrs & Multiple AN. Basilar AN : 5 cases \\
\hline Yasui, et $\mathrm{al}^{34)}$ & 1997 & 2.3 & 234 & 59.6 & $75.1 \mathrm{Mos}$ & No follow-up in $21 \%$ out of 360 cases \\
\hline Multiple AN & & 3.2 & 60 & & & \\
\hline Cases with infarction & & 2.2 & 108 & & & \\
\hline Cases with ICH & & 3.2 & 27 & & & \\
\hline Others & & 3.6 & 39 & & & \\
\hline Rinkel, et $\mathrm{al}^{20)}$ & 1998 & & & & & Review of literature \\
\hline Multiple AN & & 1.4 & 1,997 & & & \\
\hline Incidental AN & & 0.8 & 1,145 & & & \\
\hline Suga, et $\mathrm{al}^{27)}$ & 2001 & 2.8 & 590 & 63.5 & 32.6 Mos & Summary of results at 14 centers \\
\hline $\begin{array}{l}\text { International Cooperative } \\
\text { Study }{ }^{30)}\end{array}$ & 1998 & & 1,449 & & 8.3 Yrs & Cases during 21 Yrs at 53 centers \\
\hline Multiple AN & & & 722 & 49.4 & & \\
\hline Under $10 \mathrm{~mm}$ & & 0.56 & & & & \\
\hline Over $10 \mathrm{~mm}$ & & 0.64 & & & & \\
\hline Incidental AN & & & 727 & 56.0 & & \\
\hline Under $10 \mathrm{~mm}$ & & 0.05 & & & & \\
\hline Over $10 \mathrm{~mm}$ & & 0.95 & & & & \\
\hline Rosen $\varnothing \mathrm{rn}$, et al ${ }^{22)}$ & 1993 & 2.0 & & & & $\begin{array}{l}\text { Incidence of unruptured AN: } 0.5 \% \\
\text { Incidence of SAH : } \\
\quad 10 \text { per } 100,000 \text { persons per year }\end{array}$ \\
\hline Saito $^{23)}$ & 1996 & & & & & Over 40 Yrs, Incidence of SAH : \\
\hline $\begin{array}{l}\text { Incidence of } \\
\text { unruptured AN : } 3 \%\end{array}$ & & 1.3 & & & & 20 per 50,000 persons per year \\
\hline $\begin{array}{l}\text { Incidence of } \\
\text { unruptured AN }: 4 \%\end{array}$ & & 1.0 & & & & \\
\hline Hashi, et al ${ }^{5)}$ & 1999 & & & & & Calculated by incidence of unruptured \\
\hline $40 \sim 59$ Yrs & & 0.77 & & & & AN by brain checking and incidence of \\
\hline $60 \sim 69$ Yrs & & 1.06 & & & & SAH in Hisayama \\
\hline $70 \sim 79$ Yrs & & 1.94 & & & & \\
\hline Iwamoto, et al ${ }^{7)}$ & 1999 & Over 1.7 & $\begin{array}{l}1,230 \\
\text { (Autops) }\end{array}$ & cases) & & $\begin{array}{l}29 \text { ruptured AN out of } 57 \text { AN } \\
\text { Posterior circulation AN : } 6 \text { cases }\end{array}$ \\
\hline
\end{tabular}

AN : aneurysms multiple AN : unruptured AN associated with ruptured AN $\quad$ Yrs : years $\quad$ Mos : months

症候性未破裂脳動脈瘤の手術成績を推測する.

\section{1 多施設での結果を総合した報告}

King ${ }^{11)}$ は 1966〜1992 年までの文献 28 編から平均 48.6 歳の 733 例の結果を分析し，死亡率，悪化率は破裂 脳動脈瘤との合併例 292 例では $1.4 \%$ と $3.4 \%$, 偶然発見 例 289 例では $0.7 \%$ と $4.8 \%$, 分類不能例では $0.6 \%$ と $4.0 \%$ であり，各群間の值に差はなかったと報告した。 この報告の症例は, $94 \%$ テント上脳動脈瘤, $72 \%$ $10 \mathrm{~mm}$ 以下の脳動脈瘤であり, 脳動脈瘤の部位や大きさ により手術成績に差はなかったと述べている.

Raaymakers $~^{18)}$ も 1966 1996 年までの文献 61 編か ら 2,460例の手術成績を分析し，巨大脳動脈瘤を除くテ
ント上未破裂脳動脈瘤の術後死亡率は $0.8 \%$, 悪化率は $1.9 \%$ であり，テント下脳動脈瘤および巨大脳動脈瘤に 比べ結果良好例が多かったと報告している.

本邦では吉本ら ${ }^{36)}$ が 8 施設の共同調査において, 1995 年より 1.5 年間に経験した 70 歳代までの 154 例を分 析し, テント上脳動脈瘤 130 例では死亡 0 , 悪化 5 例 (3.8\%) で，悪化例の神経症候の程度は軽く，5例中 4 例が大きさ $20 \mathrm{~mm}$ の内頸動脈瘤例であり, 残り 1 例が $10 \mathrm{~mm}$ の前交通動脈瘤であったとしている.

先出の国際共同研究では ${ }^{30)}$, 後向き調査と同じ 53 施 設で手術成績に関する前向き調查を 1991〜 1995年の期 間で行っている，その結果，死亡率，悪化率は破裂脳動 脈临に伴う 197 例では $1.0 \%$ と $12.1 \%$ ，他の症状疾患で 
発見された 798 例では $3.8 \%$ と $12.0 \%$ であたとしてい る.この報告では, 巨大脳動脈瘤とテント下脳動脈瘤が, 破裂脳動脈瘤に伴った群では $1.5 \%$ と $8.8 \%$ ，偶然発見群 では $7.1 \%$ と $10.3 \%$ 含まれ，後者では占拠性病変として の症状で発見された例が $6 \%$ 存在している。しかし，脳 動脈瘤の部位や大きさは手術成績と相関はなく，年跲の みが悪化率に影響を及ぼしたとし，死亡+悪化率は 44 歳以下では $6.5 \% ， 45 \sim 64$ 歳では $14.4 \% ， 65$ 歳以上では $32 \%$ であったと報告している。

\section{2 単独施設での報告}

Solomon ${ }^{26)}$ は占拠性病変としての症状を呈した 36 例とテント下脳動脈瘤 34 例を含む 202 例を検討し，術 後軽度合併症および重度合併症の出現率は，結果良好例 は $10 \mathrm{~mm}$ 以下で $3.8 \%, 1.3 \%, 11 \sim 25 \mathrm{~mm}$ で $4 \%, 7 \%$, $25 \mathrm{~mm}$ 以上で $10 \% ， 16 \%$ であり，脳動脈瘤の大きさが 手術成績に影響すると報告したが，脳動脈瘤の存在部位 別に成績は述べられていない。

Khanna $ら^{10)}$ も 172 例を検討し, 軽度悪化率, 重度悪 化率および死亡率は後上方向きの前交通動脈瘤，傍前床 突起脳動脈瘤，症候性海綿静脈洞部動脈瘤を含む複雑な テント上脳動脈瘤では，おのおの $23.1 \%, 11.5 \%, 7.7 \%$, それ以外の単純なテント上脳動脈瘤では，おのおの $12.9 \% ， 3.2 \% ， 0.8 \%$ とし，脳動脈瘤の大きさが $10 \mathrm{~mm}$ 未満では $16.1 \% ， 4.8 \% ， 0 \% ， 10 〜 25 \mathrm{~mm}$ では $9.0 \%$ ， $7.7 \%, 3.8 \%, 25 \mathrm{~mm}$ 以上では $25.0 \%, 9.4 \%, 6.2 \%$ あ るとしている。

本邦の報告では，安井ら ${ }^{35)}$ はテント下脳動脈瘤 31 例 を含む 76 歳までの 200 例を分析し，死亡0，一過性悪化 32 例 $(16 \%)$ ，悪化 10 例（5\%）とし，テント上脳動脈 瘤 254 個では死亡0，悪化 6 例 (2.4\%)，脳動脈瘤の大き さ別畽化率は $10 \mathrm{~mm}$ 未満では $0.5 \%, 10 \sim 14 \mathrm{~mm}$ では $8.0 \% ， 15$ 24 mmでは $12.9 \%$ であったと報告し，奥山 $ら^{16)}$ は，テント下脳動脈瘤例 42 例含む 378 例の分析を 行い，死亡0，軽度あるいは一過性悪化 18 例 (4.8\%), 重度悪化 10 例 $(2.6 \%)$ で，脳動脈瘤の大きさとの相関 はなかったと報告している.

また瀧沢ら ${ }^{29)}$ は，テント下脳動脈瘤 12 例を含む 123 例の結果は，死亡 1 例 $(0.8 \%)$ ，悪化 3 例 $(2.4 \%)$ であ り, 悪化 2 例は巨大内頸動脈瘤と脳底動脈瘤であったと し，鈴木ら ${ }^{28)}$ は巨大脳動脈瘤 6 例とテント下脳動脈瘤 12 例を含む 96 例を分析し，死亡0，悪化 5 例 $(5.2 \%)$ ， 坂井ら ${ }^{25)}$ は巨大脳動脈瘤 10 個を含む109個のテント上 脳動脈瘤で軽度悪化 3 例 $(2.8 \%)$ ，重度悪化 4 例（3.7\%） で，これら 7 例中 5 例は巨大脳動脈瘤 3 例を含む $20 \mathrm{~mm}$
Table 2 Surgical results for cases of supratentorial asymptomatic unruptured aneurysms except giant aneurysms

\begin{tabular}{|c|c|c|c|c|c|c|}
\hline \multirow{2}{*}{$\begin{array}{l}\text { Location of } \\
\text { aneurysm }\end{array}$} & \multicolumn{5}{|c|}{ Overall surgical results } & \multirow{2}{*}{ Total } \\
\hline & GR & $\mathrm{MD}$ & $\mathrm{SD}$ & VG & Death & \\
\hline ICA & 37 & 1 & 0 & 0 & 0 & 38 \\
\hline $\mathrm{MCA}$ & 30 & 0 & 0 & 0 & 0 & 30 \\
\hline AComA & 10 & 1 & 0 & 0 & 0 & 11 \\
\hline DACA & 3 & 0 & 0 & 0 & 0 & 3 \\
\hline Multiple & 24 & 1 & 1 & 0 & 0 & 26 \\
\hline Total & $\begin{array}{c}104 \\
(96 \%)\end{array}$ & $\begin{array}{c}3 \\
(3 \%)\end{array}$ & $\begin{array}{c}1 \\
(1 \%)\end{array}$ & $\begin{array}{c}0 \\
(0 \%)\end{array}$ & $\begin{array}{c}0 \\
(0 \%)\end{array}$ & 108 \\
\hline
\end{tabular}

GR : good recovery $\mathrm{MD}:$ moderate disability $\mathrm{SD}:$ severe disability VG: persistent vegetative state ICA : internal carotid artery MCA : middle cerebral artery AcomA : anterior communicating artery DACA : distal anterior cerebral artery

以上の脳動脈瘤であったと報告している.

\section{3 われわれの成績}

現在までに 115 例のテント上無症候性未破裂脳動脈瘤 の手術を施行したが，115例中最大径 $25 \mathrm{~mm}$ 以上の巨大 脳動脈瘤 7 例を除く 108 例では，145個の脳動脈瘤が認 められた。平均年齢は 59.2 歳で, 70 歳代が 19 例含まれ, 75 歳以上は 6 例存在した。脳動脈溜の存在部位は内頸動 脈 38 例, 中大脳動脈 30 例, 前交通動脈 11 例, 前大脳動 脈 3 例, 多発性例 26 例であった。脳動脈瘤発見のきっ かけは脳梗塞 11 例, 脳内血腫 2 例, 脳動静脈奇形 1 例, 脳腫瘍 2 例，頭痛，めまいなどの症状 78 例で，残り 14 例は破裂脳動脈瘤に伴った未破裂脳動脈瘤を別時期に手 術した例であった。

手術は脳動脈溜径が $2 \mathrm{~mm}$ 以下のごく小さな脳動脈溜 5 個を含む計 8 個を除き 137 個（94\%）でネック・ク リッピングを施行した，術後死亡例はなく，4例 (4\%) で神経症状が出現したが，うち視野障害を生じた 2 例と 術後 5 日目に軽度片麻痺を生じた 1 例は社会復帰してお り, severe disabilityの1例は脳梗塞により生じた片麻㽻 が術後增悪した例であった。なお，70歳以上の 19 例で は術後神経症状の出現を認めた例はなかった (Table 2). 巨大脳動脈瘤 7 例は, 全例ネック・クリッピングを施行 した。術後死亡例はなく，1例で軽度の，1例で中等度 の片麻㽻の出現を認めた（Table 3）.

\section{4 手術成績のまとめ}

これまでの報告を統合すると, 成績の悪い国際共同研

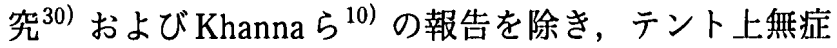
候性未破裂脳動脈瘤の手術成績は死亡率 $1 \%$ 以下で, 特 
Table 3 Surgical result in cases with supratentorial asymptomatic unruptured giant cerebral aneurysms

\begin{tabular}{cccccccc}
\hline $\begin{array}{c}\text { Case } \\
\text { No. }\end{array}$ & Age & Sex & $\begin{array}{c}\text { Clinical } \\
\text { signs }\end{array}$ & $\begin{array}{c}\text { Location of } \\
\text { aneurysms }\end{array}$ & $\begin{array}{c}\text { Surgical } \\
\text { procedures }\end{array}$ & $\begin{array}{c}\text { Surgical } \\
\text { result }\end{array}$ & Others \\
\hline 1. & 52 & F & Convulsion & ICA & Clipping & GR & \\
2. & 59 & F & Headache & ICA & Clipping & SD & Hemiparesis \\
3. & 59 & F & Headache & ICA & Clipping & GR & \\
4. & 65 & F & Headache & ICA & Clipping & GR & \\
5. & 51 & M & Headache & MCA & Clipping & MD & Hemiparesis \\
6. & 52 & F & Minor stroke & MCA & Clipping & GR & \\
7. & 55 & F & Minor stroke & MCA & Clipping & GR & \\
\hline
\end{tabular}

Table 4 Surgical outcome in cases of supratentorial asymptomatic unruptured aneurysms

\begin{tabular}{|c|c|c|c|c|c|c|}
\hline Authors & Year & $\begin{array}{l}\text { No. of } \\
\text { cases }\end{array}$ & $\begin{array}{c}\text { Mean } \\
\text { age } \\
\text { (Yrs) }\end{array}$ & Mortality & Morbidity & Others \\
\hline King, et al ${ }^{11)}$ & 1994 & 733 & 48.6 & $1.0 \%$ & $4.1 \%$ & Review of literature. \\
\hline Multiple AN & & 292 & & $1.4 \%$ & $3.4 \%$ & Supratentorial AN : 94\% \\
\hline Incidental AN & & 273 & & $0.7 \%$ & $4.8 \%$ & AN under $10 \mathrm{~mm}: 72 \%$ \\
\hline Others & & 145 & & $0.6 \%$ & $4.0 \%$ & \\
\hline Raaymakers, et al ${ }^{18)}$ & 1998 & & & $0.8 \%$ & $1.9 \%$ & $\begin{array}{l}\text { Review of literatures } \\
\text { Except giant AN }\end{array}$ \\
\hline Yoshimoto, et $\mathrm{al}^{36)}$ & 1997 & 130 & & 0 & $3.8 \%$ & Summary of 8 centers \\
\hline $\begin{array}{l}\text { International Cooperative } \\
\text { Study }{ }^{30)}\end{array}$ & 1998 & & & & & Prospective study at 53 centers \\
\hline Multiple AN & & 197 & 47.2 & $1.0 \%$ & $12.1 \%$ & Giant AN 1.5\%, Infratentorial AN 8.8\% \\
\hline Incidental AN & & 79 & 53.0 & $3.8 \%$ & $12.0 \%$ & Giant AN 7.1\%, Infratentorial AN 10.3\% \\
\hline Solomon, et $\mathrm{al}^{26)}$ & 1994 & 202 & & & & Space occupying lesions : 36 cases \\
\hline Under $10 \mathrm{~mm}$ & & 77 & & & $5.0 \%(1 \%)$ & Infratentorial AN : 34 cases \\
\hline $11 \sim 25 \mathrm{~mm}$ & & 76 & & & $10.5 \%(7 \%)$ & ( ) : cases of severe deficits \\
\hline Over $25 \mathrm{~mm}$ & & 49 & & & $26.5 \%(16 \%)$ & \\
\hline Khanna, et al ${ }^{10)}$ & 1996 & & & & & \\
\hline $\begin{array}{l}\text { Simple anterior } \\
\text { circulation AN }\end{array}$ & & 124 & & $0.8 \%$ & $16.1 \%(3.2 \%)$ & $(\quad)$ : cases of severe deficits \\
\hline $\begin{array}{c}\text { Complex anterior } \\
\text { circulation AN }\end{array}$ & & 26 & & $7.7 \%$ & $34.6 \%(11.5 \%)$ & \\
\hline Yasui, et at ${ }^{35)}$ & 1998 & $200 \mathrm{AN}$ & 58.0 & 0 & $5.0 \%$ & Infratentorial AN : 31 cases \\
\hline Okuyama, et al ${ }^{16)}$ & 1998 & 378 & & 0 & $7.4 \%(2.6 \%)$ & $\begin{array}{l}\text { Infratentorial AN : } 42 \text { cases } \\
(\quad): \text { cases of severe deficits }\end{array}$ \\
\hline Takizawa, et al ${ }^{29)}$ & 1998 & 123 & & $0.8 \%$ & $2.4 \%$ & Infratentorial $\mathrm{AN}: 12$ cases \\
\hline Suzuki, et al ${ }^{28)}$ & 1998 & 96 & 54.9 & 0 & $5.2 \%$ & $\begin{array}{l}\text { Giant AN }: 6 \text { cases } \\
\text { Infratentorial AN }: 12 \text { cases }\end{array}$ \\
\hline Sakai, et al ${ }^{25)}$ & 1998 & $109 \mathrm{AN}$ & & 0 & $6.4 \%(3.7 \%)$ & $(\quad)$ : cases of severe deficits \\
\hline Nukui, et al & 2002 & & & & & Giant AN : 10 AN \\
\hline Under $25 \mathrm{~mm}$ & & 108 & 59.2 & 0 & $4 \%$ & \\
\hline Over $25 \mathrm{~mm}$ & & 7 & 56.1 & 0 & $28.6 \%(14.3 \%)$ & ( ) : cases of severe deficits \\
\hline
\end{tabular}

AN : aneurysms Multiple AN : unruptured AN associated with ruptured aneurysms Yrs : years old

に本邦での多数例の報告では死亡率 0 が多く，術後悪化 率は $4 \%$ 以下との報告が多い，また，手術成績は脳動脈 瘤の大きさと相関し, 脳動脈瘤が大きいほど術後悪化率 が上昇している（Table 4).

\section{5 手術の効果に関する推計学的検討}

King $5^{12)}$ は年間出血率 $1 \%$ ，手術の死亡率 $1 \%$ ，悪化 率 $4.1 \%$ 等の数字を用い費用対効果の面から検討し，患 者の平均余命が 13 年以上あり, 診断後 $\mathrm{QOL}$ の低下を経 
験した例では迅速な手術が効果的であると述べている.

Chang $ら^{3)}$ は，クモ膜下出血後死亡率を $50 \%$ とし，年 間出血 $1 \%$ ，手術死亡率 $1 \%$ と仮定すると，手術により 平均余命が 40 歳で 3.9 年, 50 歳で 2.4 年, 60 歳で 1.3 年, 70 歳で 0.6 年延びると報告している.

しかしこれらの推計では，脳動脈溜破裂による家族や 社会に及ぼす精神的・経済的影響が勘案されておらず， 平均余命の期間のみを取り上げ，余命における生活の質 が考慮されていないなどの問題がある.

\section{6 血管内手術}

無症候性未破裂脳動脈瘤に対する血管内手術は，主に 脳底動脈瘤や傍前床突起部動脈瘤や高齢者, 全身合併症 のある例での施行例が多く，それ以外の例では少な (2)25).

ただ Regli ${ }^{19)}$ は未破裂中大脳動脈瘤例 30 例 34 個で, 血管内手術を試みた 13 個中, 脳動脈瘤の完全閉塞が得 られたのは 2 個のみであり, 結局 32 個はクリッピング が行われたと報告している。

\section{手術適応}

1997 年に日本脳ドック学会あり方委員会により発表 された「脳ドックのガイドライン」14) で示された方針 （Table 5）は，巨大脳動脈瘤を除くテント上の無症候性 未破裂脳動脈瘤の出血率が $1 \sim 2 \%$, 手術死亡率は $1 \%$ 以 下, 悪化率は $4 \%$ 以下という現在までの結果と, 推計学的 検討で示された手術効果を考えれば妥当であるといえる.

しかし肉体的・精神的に健康な高路者が増加している 現在では，70歳以上の高齢者での出血率は必ずしも低 くなく，若年者に比べ出血すると重症となる率が高く， 重症例の手術成績は著しく不良であり, 軽症例での成績 は変わらないことなどを勘案すると，70歳を越えても 手術適応はあると考えられる。 また，動脈熘の大きさに 関しても， $5 \mathrm{~mm}$ 以下の未破裂脳動脈瘤も出血をきたす 可能性があること，および破裂脳動脈瘤の約 $30 \%$ が $5 \mathrm{~mm}$ 以下であることなどを勘案すると $5 \mathrm{~mm}$ 以下の動脈 瘤も手術対象とすべきであると思われる。

手術法に関しては，現在のところ手技が確立され，手 術死亡率, 悪化率も低い直達手術が第一選択であるが, 全身状態の悪い例や手術が困難な部位の未破裂脳動脈瘤 では血管内手術を考慮する必要がある，さらに，巨大脳 動脈瘤は手術手技がむずかしく，手術成績もやや不良で あるため, 現在のところ70歳以下の例で直達手術の適 応があるとしてよいと考えられる。
Table 5 Criteria for surgery of supratentorial asymptomatic unruptured cerebral aneurysms $^{14)}$

1. Good physical and neurological condition

2. Under 80 years of age

(Under 70 years of age in cases of giant aneurysms)

3. Strong desire for operation

4. Good informed consent

5. Irrespective of aneurysmal size

\section{おわりに}

テント上の無症候性未破裂脳動脈瘤の自然歴, 手術成 績等につき文献的考察を加え, 現在考えられる手術適応 を検討した。

本稿の一部は, 第 21 回日本脳神経外科コングレス（2001，山形） プレナリーセッションにて発表した.

\section{文 献}

1) Ausman JI: Editor's note : Treatment of Unruptured cerebral aneurysms. Surg Neurol 51: 355-362, 1999.

2) Brilstra EH, Rinkel GJE, van der Graaf Y, van Roiij WJJ, Algra A: Treatment of intracranial aneurysms by embolization with coils : A systematic review. Stroke 30:470476, 1999.

3) Chang HS, Kirino $T$ : Quantification of operative benefit for unuptured cerebral aneurysms: A theoretical approach. $J$ Neurosurg 83: 413-420, 1995.

4) Dickey PS : Do selection and referral bias explain the apparent $10 \mathrm{~mm}$ rupture threshold for unruptured aneurysms? J Neurosurg 92: 544, 2000.

5）端 和夫：脳ドックと脳動脈瘤。蹦林と研究 $75: 31$ $38,1999$.

6) 平成 11 年度厚生科学研究費補助金, 健康科学総合研究 事業研究報告書. 脳検診で発見される未破裂脳動脈爈例 の経過観察に関する研究

7) Iwamoto H, Kiyohara Y, Fujishima M, Kato I, Nakayama K, Sueishi K, Tsuneyoshi M: Prevalence of intracranial saccular aneurysms in a Japanese community based on a consecutive autopsy series during a 30 -year observation period : The Hisayama Study. Stroke 30: 1390-1395, 1999.

8) Juvela S, Porras M, Heiskanen $0:$ Natural history of unruptured intracranial aneurysms: A long-term followup study. J Neurosurg 79: 174-182, 1993.

9) Kassell NF, Torner JC, Haley EC Jr, Jane JA, Adams HP, Kongable GL: The International Cooperative Study on the Timing of Aneurysm Surgery, Part I: Overall management results. J Neurosurg 73:18-36, 1990.

10) Khanna RK, Malik GM, Qureshi N: Predicting outcome following surgical treatment of unruptured intracranial aneurysms: A proposed grading system. J Neurosurg $\mathbf{8 4}$ : 49-54, 1996.

11) King JT Jr, Berlin JA, Flamm ES : Morbidity and mortality from elective surgery for asymptomatic, unruptured, intracranial aneurysms: A meta-analysis.J Neurosurg $\mathbf{8 1}$ 
: 837-842, 1994.

12) King JT Jr, Glick HA, Mason TJ, Flamm ES : Elective surgery for asymptomatic, unruptured, intracranial aneurysms : A cost-effectiveness analysis. J Neurosurg 83: 403-412, 1995.

13) Kiyohara $Y$, Ueda K, Hasuo $Y$, Wada J, Kawano H, Kato I, Shinkawa A, Ohmura T, Iwamoto H, Omae T, Fujishima $\mathrm{M}$ : Incidence and prognosis of subarachnoid hemorrhage in a Japanese rural community. Stroke 20:1150-1155, 1989.

14）日本脳ドック学会脳ドックあり方委員会 : 脳ドックのガ イドライン. 1997.

15）㙺井英明：高㱓者破裂脳動脈瘤の手術適応。脳と循環 4: 43-47, 1999.

16) 奥山 徹, 斎藤孝次, 平野 亮, 高橋 明, 稲垣 徹, 佐々木祐典：無症候性未破裂脳動脈瘤の外科治䝤.The Mt. Fuji Workshop on CVD 16:170-173, 1998.

17) Orz $Y$, Kobayashi S, Osawa M, Tanaka $Y$ : Aneurym size: A prognostic factor for rupture. Br J Neurosurg 11:144149, 1997.

18) Raaymakers TWM, Rinkel GJE, Limburg M, Algra A : Mortality and morbidity of surgery for unruptured intracranial aneurysms : A meta-analysis. Stroke 29: 15311538, 1998.

19) Regli L, Uske A, de Tribolet N: Endovascular coil placement compared with surgical clipping for the treatment of unruptured middle cerebral artery aneurysms: A comsecutive series.J Neurosurg 90: 1025-1030, 1999.

20) Rinkel GJE, Djibuti M, Algra A, van Gijn J: Prevalence and risk of rupture of intracranial aneurysms : A systemic review. Stroke 29:251-256, 1998.

21) Rinne J, Hernesniemi J, Puranen M, Saari J : Multiple intracranial aneurysms in a defined population : Prospective angiographic and clinical study. Neurosurgery 35: 803-808, 1994.

22) Rosen $ø$ rn J, Eskesen V: Does a safe size-limit exist for unruptured intracranial aneurysms ? Acta Neurochir (Wien) 121: 113-118, 1993.

23）齋藤 勇：無症候性脳動脈溜一その対応と問題点．脳外 24:875-884, 1996.

24）啒藤 勇：無症候性脳動脈溜への対応. 脳と循環 4 :
49-54, 1999.

25）坂井信幸，菊池啨彦，滝 和郎，永田 泉，宮本 享, 中原一郎, 野崎和彦, 高橋 潤, 青木友和, 高橋 淳, 橋本信夫：無症候性脳動脈瘤の治療一最近 5 年間の治療 結果加ら. The Mt. Fuji Workshop on CVD 16:153-157, 1998.

26) Solomon RA, Fink ME, Pile-Spellman J: Surgical management of unruptured intracranial aneurysms. J Neurosurg 80:440-460, 1994.

27）菅 貞郎，河瀬 斌：本邦における未破裂脳動脈溜治療 の現状と破裂率一第29回日本脳卒中の外科学会シンポ ジウム応募演題の総括. 脳卒中の外科 29:160-165, 2001.

28）鈴木偷保，佐藤直也，大間々真一，菅原 淳，上肥 守， 三浦一之, 小川 彰: 未破裂脳動脈瘤一われわれの治療 方針. The Mt. Fuji Workshop on CVD 16:148-152, 1998.

29）瀧沢克已, 上山博康, 小林延光, 高村春雄: 無症候性脑 動脈瘤の治療方針. The Mt. Fuji Workshop on CVD 16: 174-177, 1998.

30) The International Study of Unruptured Intracranial Aneurysms Investigators : Unruptured intracranial aneurysms-risk of rupture and risks of surgical intervention. NEngl J Med 339: 1725-1733, 1998.

31) Wiebers DO, Piepgras DG, Huston J: Unruptured intracranial aneurysms. NEngl J Med 340: 1441-1442, 1999.

32）八木伸一, 貫井英明, 西ヶ谷和之, 宮沢伸彦, 墹越 徹, 深町 彰, 佐々木秀夫: 高龄者破裂脳動脈瘤直達手術例 の転帰の予測。脳卒中の外科 27:210-215, 1999.

33) Yasui N, Magarisawa S, Suzuki A, Nishimura H, Okudera $\mathrm{T}$, Abe $\mathrm{T}$ : Subarachnoid hemorrhage caused by previously diagnosed, previously unruptured intracranial aneurysms: A retrospective analysis of 25 cases. Neurosurgery 39 : 1096-1101, 1996.

34) Yasui N, Suzuki A, Nishimura H, Suzuki K, Abe T: Longterm follow-up study of unruptured intracranial aneurysms. Neurosurgery $40: 1155-1160,1997$.

35）安井信之, 西村弘美: 無症候性末破裂脳動脈瘤の手術治 療の問題点一単一術者による手術成績の検討. The Mt. Fuji Workshop on CVD 16:166-169, 1998.

36）吉本高志, 長嶺義秀 : 無症候性未破裂脳動脈瘤の手術. 脳卒中 $19: 494-498,1997$.

\section{旨 \\ テント上無症候性未破裂脳動脈瘤の治療方針 \\ 貫井 英明 堀越 徹 八木下 勉 杉田 正夫}

テント上の無症候性未破裂脳動脈瘤の自然歴と手術成績を文献学的に検討し，下記の結果を得た。

1）年間出血率は1〜2\%であり，国際共同研究で示された出血率は対象とした症例の選択にバイア スがかっかている可能性が高く，考慮しなくてよいと考えられる.

2） $5 \mathrm{~mm}$ 以下の小さな脳動脈瘤および 70 歲以上の高齢者の脳動脈瘤も出血する可能性がある.

3）手術成績は死亡率 $1 \%$ 以下，墨化率 $4 \%$ であった.

4）手術法は現在のところ直達手術が第一に考慮されるべき方法である.

以上の結果から，巨大脳動脈瘤を除くとテント上の無症候性未破裂脳動脈瘤は，正常な日常生活が 可能で, 重篤な全身合併のない例では $5 \mathrm{~mm}$ 以下の脳動脈瘤を含め 70 歳以上でも手術適応があり, 巨大脳動眽瘤では手術がむずかしく手術成績もやや悪いことから，70歳以下の例で手術適応がある と考える. 